\title{
TESTING OF PNEUMATIC VACUUM AND PRESSURE SOWING MACHINES
}

\author{
Mursec, B.; Vindis, P.; JANZEKOVIC, M.; BANAJ, D.; Kolar, M. \\ \& KRISTL, J.
}

Abstract: We tested two sowing machines in completely identical conditions at different speeds of sowing. The pneumatic vacuum sowing machine OLT and the pneumatic pressure sowing machine Aeromat - Becker are compared in manuscript. We were interested in adequacy of sowing at different working speeds and to find out the optimum working speed for the individual sowing machine. The parameters such as depth of sowing, working efficiency, distance between seeds in the sowing row and inter - row distance were measured and calculated. For successful sowing it is necessary to know adequacy of the soil for sowing, technical properties of the sowing machine and biotechnical characteristics of the seed. Distance between seeds in the sowing row must enable the plants to have optimum conditions for their growth and development. The tests were aimed at defining the most suitable sowing speed for both sowing machines on the basis of measured data. Cultivation requires much money invested and work performed per unit of area. The pneumatic vacuum machine OLT has the optimum sowing speed $8 \mathrm{~km} / \mathrm{h}$ and the sowing machine Aeromat Becker $10 \mathrm{~km} / \mathrm{h}$.

Key words: Sowing machines, depth of sowing, working speed, distance between seeds in the sowing row, inter - row distance
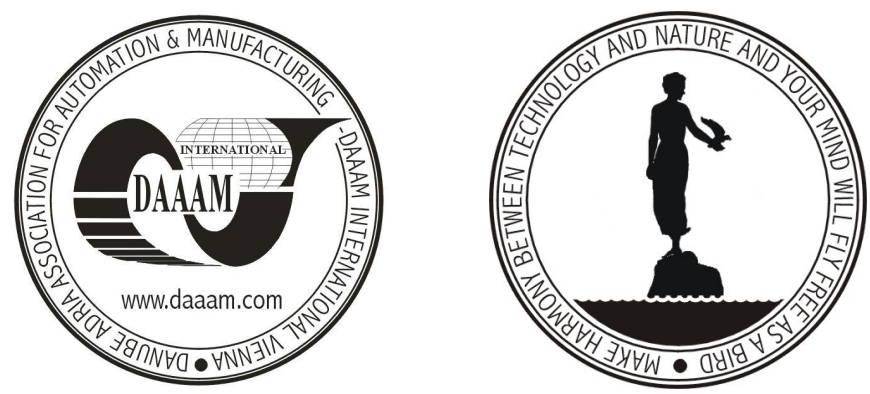

Authors' data: Assoc. Prof. Mursec, B[ogomir]*; Bs. Agric. Eng. Vindis, P[eter]*; Asst. Prof. Janzekovic, M[arjan]*; Full Prof. Banaj, D[uro]**; Assistant Professor Kolar, M[itja]***, M. Sc. Kristl, J[anja]*, * University of Maribor, Faculty of Agriculture, 2000 Maribor, Slovenia, ** University of Osijek, Faculty of Agriculture, 31000 Osijek, Croatia, *** University of Maribor, Faculty of Chemistry and Chemical Technology, 2000 Maribor, Slovenia, bogomir.mursec@uni-mb.si, peter.vindis@uni-mb.si, marjan.janzekovic@unimb.si,djbanaj@pfos.hr, mitja.kolar@uni-mb.si,janja.kristl@uni-mb.si

This Publication has to be referred as: Mursec, B.; Vindis, P.; Janzekovic, M.; Banaj, D.; Kolar, M. \& Kristl, J. (2007). Testing of pneumatic vacuum and pressure sowing machines, Chapter 01 in DAAAM International Scientific Book 2007, B. Katalinic (Ed.), Published by DAAAM International, ISBN 3-901509-60-7, ISSN 1726-9687, Vienna, Austria

DOI: $10.2507 /$ daaam.scibook.2007.01 